\title{
Hygienic-health quality and microbiological hazard of clandestine Minas Frescal cheese commercialized in north Tocantins, Brazil
}

\section{Qualidade higiênico-sanitária e perigos microbiológicos de queijos Minas Frescal clandestinos comercializados no norte do Tocantins}

\author{
Monike da Silva Oliveira ${ }^{1 *}$; Isac Gabriel Cunha dos Santos ${ }^{2}$; Bianca Pereira Dias ${ }^{3}$; \\ Cristiane Alves Nascimento4; Ézio Machado Rodrigues²; José Carlos Ribeiro \\ Júnior ${ }^{5}$; Amauri Alcindo Alfieri6; Bruna Alexandrino ${ }^{5}$
}

Highlights

Clandestine Minas Frescal cheeses can compromise public health.

Clandestine samples do not meet all microbiological quality standards.

Coagulase-positive Staphylococcus at high counts was identified.

The presence of E. coli with pathogenic potential (EPEC, STEC, and EHEC).

\begin{abstract}
Cheese is a popular product that integrates the diet of the majority of the population, almost on a daily basis. It is rich in nutrients and, therefore, also an excellent substrate for the multiplication of microorganisms, including pathogens. The microbiological contamination of these products is highly relevant to the industry, resulting in an economic loss, and to public health, due to the risk of causing foodborne diseases. The aim of this study was to evaluate the hygienic-sanitary quality and the presence of bacterial pathogens in the clandestine Minas Frescal cheeses sold in the street open markets of Araguaína, TO, Brazil. Twentyone samples were collected to evaluate the presence of total (TC) and thermotolerant (TTC) coliforms, Escherichia coli, and the pathotypes enteropathogenic E. coli (EPEC), and shiga toxin-producing E. coli

1 Student PhD, Program in Tropical Medicine and Public Health, PPGMTSP, Federal University of Goiás, UFG, Goiânia, GO, Brazil. E-mail: nikemedvet@yahoo.com.br

2 Student's Master's, Program in Animal Health and Public Health in the Tropics, PPGSaspt, Federal University of Tocantins, UFT, Araguaína, TO, Brazil. E-mail: isacgabrielsc@gmail.com; ezio1970@hotmail.com

3 Student Graduate Veterinary Medicine, UFT, Araguaína, TO, Brazil. E-mail: biianca.p.dias@gmail.com

${ }^{4}$ Laboratory Technique, Food Microbiology Laboratory, LabMA, Federal University of Tocantins, UFT, Araguaína, TO, Brazil. E-mail: crisalves_9@hotmail.com

5 Profs. PhDs, School of Veterinary Medicine and Animal Science, EMVZ, Federal University of Tocantins, UFT, Araguaína, TO, Brazil. E-mail: jcribeiro@uft.edu.br; bralexandrino@uft.edu.br

${ }^{6}$ Prof. PhD., National Institute of Science and Technology for the Milk Production Chain, INCT, Milk Chain, State University of Londrina, UEL, Londrina, PR, Brazil. E-mail: alfieri@uel.br

* Author for correspondence
\end{abstract}

Received: July 29, 2020 - Approved: Nov. 02, 2020 
(STEC) and enterohemorrhagic E. coli (EHEC), coagulase-positive staphylococci (CPS), Salmonella spp., and Listeria monocytogenes. The results showed that $100 \%$ of the cheese samples were in disagreement with the maximum standards of TC and TTC defined in the Brazilian legislation that regulates food quality

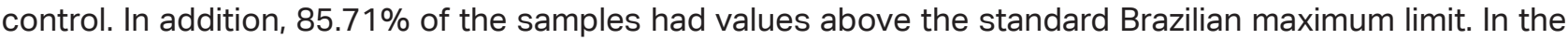
study of diarrheagenic E. coli, $52.38 \%, 66.6 \%$, and $4.76 \%$ of the samples were positive for EPEC, STEC, and EHEC, respectively, indicating fecal origin contamination of the samples and a potential consumer risk. No Salmonella spp. or Listeria monocytogenes were detected in these cheese samples. The high count of total and thermotolerant coliforms found in the samples demonstrates unsatisfactory sanitary conditions in the production, storage, and/or commercialization of this food product. The presence of EPEC, STEC, EHEC, and coagulase-positive staphylococci at high concentrations shows the health risk of the imminent consumption of Minas Frescal cheese.

Key words: EHEC. EPEC. Foodborne diseases. Public Health. STEC.

\section{Resumo}

O queijo é um produto popular que compõe quase que diariamente a dieta da população. É rico em nutrientes e por isso também um excelente meio de multiplicação de micro-organismos, inclusive os patogênicos. A contaminação microbiológica desses produtos assume destacada relevância tanto para a indústria, pelas perdas econômicas, como para a saúde pública, pelo risco de causar doenças transmitidas por alimentos, sobretudo quando produzido clandestinamente. Diante do exposto, o objetivo desta pesquisa foi avaliar a qualidade higiênico-sanitária e a presença de patógenos bacterianos nos queijos Minas Frescal clandestinos comercializados nas feiras livres do município de Araguaína - TO. Foram coletadas 21 amostras avaliando-se a presença de coliformes totais (CT) e termotolerantes (CTT), Escherichia coli e, por abordagem molecular, caracterizar os patótipos enteropatogênica (EPEC), produtora de toxina shiga (STEC) e enterohemorrágica (EHEC), estafilococos coagulase positiva (ECP), Salmonella spp. e Listeria monocytogenes. Foi verificado que $100 \%$ das amostras de queijo estavam em desacordo com o padrão máximo de CT e CTT previstos na legislação que regulamenta seu controle de qualidade. Além desses grupos, $85,71 \%$ das amostras encontravam-se acima do limite máximo previsto para ECP. Na pesquisa de $E$. coli diarreiogênicas 476 isolados foram testados e foi verificado que $52,38 \%, 66,6 \%$ e 4,76\% das amostras de queijos foram positivas para EPEC, STEC e EHEC, respectivamente, indicando contaminação de origem fecal nas amostras e potencial presença de outros enteropatógenos. Em nenhuma amostra foi detectada a presença de Salmonella spp. e Listeria monocytogenes. A alta contagem de coliformes totais e termotolerantes encontrados nas amostras demonstram condição sanitária insatisfatória na produção, armazenamento e/ou comercialização deste alimento, potencialmente produzido com leite cru. A presença de EPEC, STEC e EHEC e estafilococos coagulase positiva em elevadas concentrações, evidenciam o iminente risco à saúde pelo consumo do queijo Minas Frescal clandestinos.

Palavras-chave: DTAs. EHEC. EPEC. Saúde Pública. STEC. 


\section{Introduction}

Milk is considered one of the most complete foods because of its high nutritional value. It consists of proteins, carbohydrates, fats, minerals, vitamins, and water, in addition to compounds with high digestibility, components that make it essential for the human diet making it widely marketed and consumed by the population, especially by children and the elderly (Salvador et al., 2012).

Milk producers, predominantly small, find in cheese production a way to add value to the product (Lopes, Carmo, Lima, \& Carvalho, 2006; Teider et al., 2019). This process is usually carried out in a rudimentary way on the rural properties themselves, without the hygienic-sanitary control determined by the Brazilian legislation to guarantee that they are safe for consumption. The fact that they are produced with raw, unpasteurized milk, implies a potential risk in their consumption, due to the non-elimination of the pathogenic microbiota that may be present, often resulting from unsatisfactory conditions in obtaining the raw material or infectious processes related to animal health (Amorim, Couto, Santana, Ribeiro, \& Ferreira, 2014).

The Collegiate Board Resolution $n^{\circ}$ 12/2001 of Agência Nacional de Vigilância Sanitária (ANVISA) is the current Brazilian law in force until December 2020, that establishes the maximum allowed parameters of microorganisms present in cheeses for the purposes of registration and inspection, namely: coliforms at $45^{\circ} \mathrm{C} / \mathrm{g}$ (5 $\times 10^{3}$ most probable number/g), coagulasepositive staphylococci $\left(5 \times 10^{3} \mathrm{MPN} / \mathrm{g}\right)$, absence of Salmonella spp./25 $\mathrm{g}$ and $L$. monocytogenes/25 g (ANVISA, 2001), and coliforms at $30^{\circ} \mathrm{C} / \mathrm{g}\left(10^{5} \mathrm{MPN} / \mathrm{g}\right)$ Ministério da Agricultura, Pecuária e Abastecimento
[MAPA], (1996), evaluating if the products are in satisfactory microbiological conditions or not.

The poor quality of production can be indicated by the presence of Escherichia coli, as it is a microorganism that indicates fecal contamination in the product (N. Silva et al., 2017). The main clinical symptoms of diarrheal $E$. coli in humans are watery diarrhea, accompanied by fever, malaise, and vomiting (J. A. Silva \& Silva, 2005). Enteropathogenic E. coli (EPEC), and shiga toxin-producing $E$. coli (STEC) and enterohemorrhagic E. coli (EHEC) have been declared as major causes of diarrhea since 1940 and continue to be related to sporadic cases of outbreaks (C. D. O. Souza et al., 2016; Gomes et al., 2016).

Staphylococcal food poisoning, which is caused by eating dairy products, such as cheese, is common and is continually reported (Carmo et al., 2002; Argudín, Mendoza, \& Rodicio, 2010; Johler et al., 2015; Sato'o et al., 2014). The milk heating process used in pasteurization inactivates Staphylococcus spp., but not the previously produced enterotoxins, which remain active in the food product for a long period (Carmo et al., 2002; Johler et al., 2015).

Salmonella spp. is the leading global foodborne disease agent, with tens of millions of cases per year worldwide (World Health Organization [WHO], 2019), including in Brazil (N. Silva et al., 2017); being one of four causes of diarrhea worldwide, and although large outbreaks of Salmonella spp. attract media attention, $60 \%$ to $80 \%$ of all cases of salmonellosis are not recognized as part of an outbreak, being classified as sporadic or even not being diagnosed as such (WHO, 2019). The consumption of milk and its derivatives is related to important pathogens 
that cause foodborne diseases, mainly due to contamination with Salmonella spp. (Elbagory, Eman, \& Eman, 2015).

The high humidity, $\mathrm{pH}$, and storage under refrigeration are factors of fresh cheeses that favor the multiplication or viability of $L$. monocytogenes. This microorganism is considered an opportunistic pathogen, since the occurrence of infection is mainly related to the immunological conditions of the affected individuals: pregnant women and the elderly, the latter being increasingly affected by human listeriosis (Cruz, Martinez, \& Destro; 2008; Fai et al., 2011).

Between 2009 and 2017 in the municipality of Araguaína, State of Tocantins, Brazil, of the nine outbreaks of foodborne diseases, five were caused by toxins produced by Staphylococcus aureus, two by E. coli, and one by Salmonella spp. (Vigilância Epidemiológica do Município de Araguaína-TO, 2019).

Due to the various reports of foodborne diseases in the world, and in the municipality of Araguaína, and the potential risk to public health due to the consumption of clandestine fresh cheeses, the objective of this work was to evaluate the hygienic-sanitary quality and the presence of bacterial pathogens in the minas frescal cheese clandestines (MFCC), marketed in street open markets in the municipality of Araguaína, Tocantins, Brazil.

\section{Materials and Methods}

\section{Sampling}

Twenty-one samples of MFCCs sold in street open markets in the municipality of Araguaína-TO, acquired between April and
June 2019, were tested. Each sample was purchased from a different trader and had a different origin. The samples were identified, placed in a transparent plastic bag for first use, packed in an isothermal box with ice, and sent to the Laboratory of Hygiene and Public Health, Federal University of Tocantins, Campus Araguaína/TO, Brazil, for immediate processing.

\section{Microorganism count}

For the analysis of total coliforms (TC) and thermotolerant coliforms (TTC), the most probable number (MPN) methodology was used, according to the APHA 9:2015 and APHA/ AWWA/WEF 9221:2012. For the isolation of isolates suggestive of $E$. coli from each tube of EC broth with growth and gas production, streaks were made on eosin methylene blue agar (EMB), and the plates were incubated at $35^{\circ} \mathrm{C}$ for 18 to 24 hours. Typical colonies (green with a metallic shine) were purified, multiplied on a plate count agar (PCA), and incubated at $35^{\circ} \mathrm{C}$ for 18 to $24 \mathrm{~h}$.

\section{Coagulase positive staphylococci}

Coagulase-positive staphylococci (CPS) were counted according to the methodology recommended by the International Organization for Standardization (ISO) 6888-1:1999/Amd 1:2003. The detection of coagulase production followed the methodology described by Costa, Pereira, Custódio and Silva (2011), in which equine plasma was used. The bacterial population was calculated according to ISO 7218:2007/ Amd 1:2003 and the results were expressed in CFU/g. 
Salmonella spp. and Listeria spp.

Qualitative analysis of Salmonella spp. and Listeria monocytogenes was performed according to the ISO 6579:2002/Amd 1:2007 modified, and ISO 11290-1:1996/Amd 1:2004 modified, respectively. The modification of both consisted of the molecular identification from isolates suspected of differential plating.

\section{Recovery of microorganisms}

The isolates suggestive of $E$. coli, Salmonella spp., and Listeria spp. were seeded in Brain Hart Infusion (BHI) broth at $37^{\circ} \mathrm{C}$ for 18 to $24 \mathrm{~h}$. Then, $0.5 \mathrm{~mL}$ of cloudy $\mathrm{BHI}$ were stored with $0.5 \mathrm{~mL}$ of glycerin and frozen at $-18^{\circ} \mathrm{C}$. These were recovered by inoculating $30 \mu \mathrm{L}$ in $3 \mathrm{~mL}$ of $\mathrm{BHI}$ broth and incubating the mixture at $37^{\circ} \mathrm{C}$ for $24 \mathrm{~h}$. One side of the cloudy $\mathrm{BHI}$ broth was streaked on PCA agar and incubated at $37^{\circ} \mathrm{C}$ for $24 \mathrm{~h}$. An isolated colony was inoculated again in $\mathrm{BHI}$ broth and incubated as previously described. Each cloudy $\mathrm{BH}$ isolate was subjected to DNA extraction.

\section{Molecular confirmation of isolates}

The isolates were confirmed using the uniplex PCR technique. DNA extraction was carried out according to Ribeiro et al. (2016). In the confirmation of pathogenic E. coli, Paton and Paton (1998) searched for pathogenic strains of enteropathogenic $E$. coli (EPEC) containing the eaeA gene, and $E$. coli producing Shiga-like toxin (STEC), by detecting the st $x$ or stx2 genes. For the confirmation of Salmonella spp., the methodology recommended by Shanmugasamy, Velayutham and Rajeswar (2011) was used, using gender-specific PCR, targeting the invA gene. For the confirmation of Listeria spp., the PCR method was used to confirm the genus by searching for the iap gene, as described by Chen and Knabel (2007). Table 1 shows the primers and amplification conditions used. Table 2 shows the quantities of each PCR component to which the samples were added for amplification. 


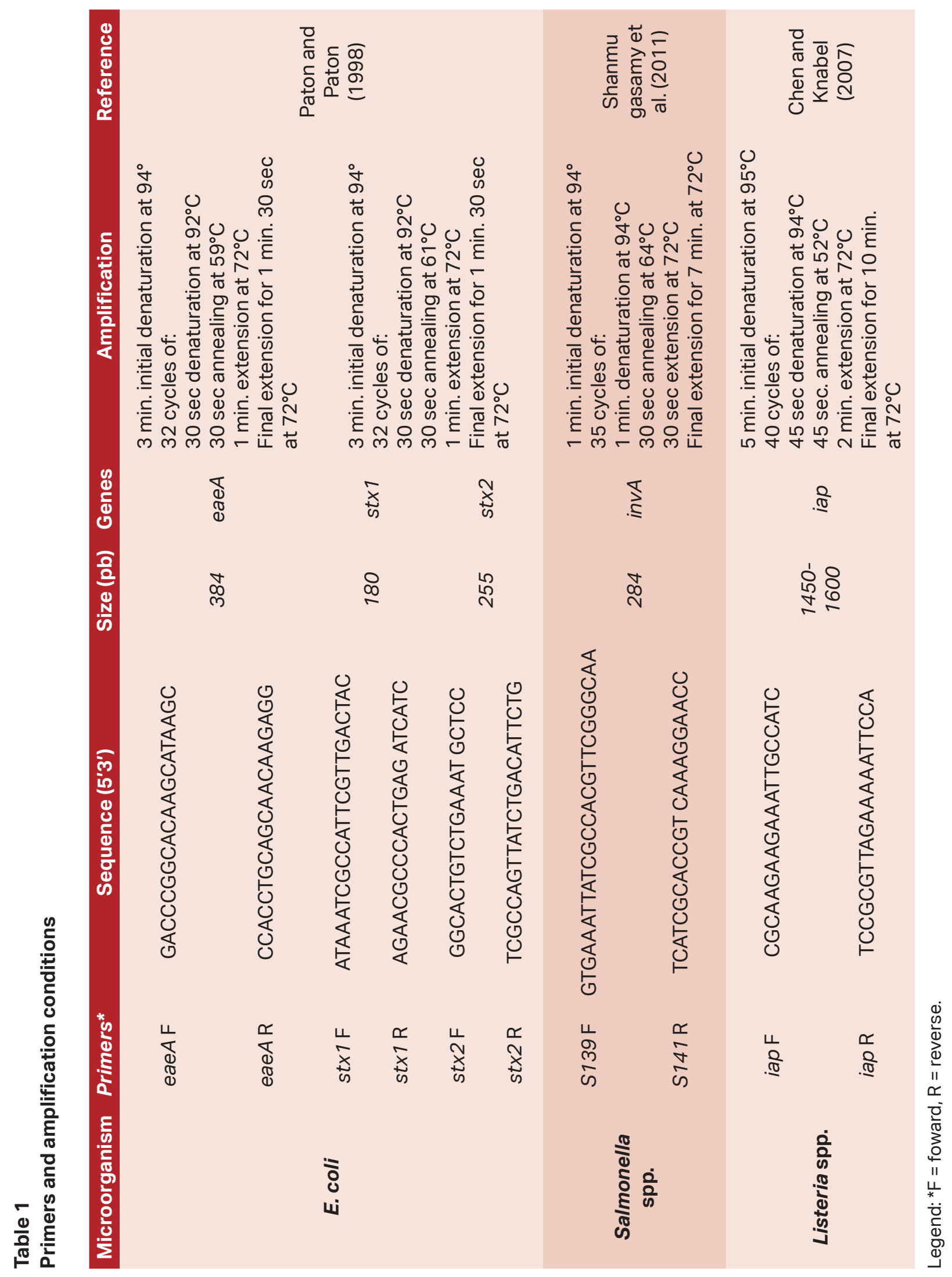


Table 2

Reagent composition and quantities (per $\mu \mathrm{L}$ ) for PCR per isolate tested in a final volume reaction of $25 \mu \mathrm{L}$

\begin{tabular}{lcc} 
& E. coli & Listeria spp. \\
\hline Ultrapure water & Salmonella spp. & 18,05 \\
$10 x$ buffer & 18,35 & 2,5 \\
$\mathrm{dNTP} 10 \mathrm{mM} /$ each & 2,5 & 0,75 \\
$\mathrm{MgCl}_{2}(50 \mathrm{mmol})$ & 0,75 & 1,0 \\
\hline Primer Foward $(10 \mathrm{pmol})$ & 0,75 & 0,75 \\
\hline Primer Reverse $(10 \mathrm{pmol})$ & 0,75 & 0,75 \\
\hline Taq DNA polymerize $(5 \mathrm{U} / \mu \mathrm{L})$ & 0,75 & 0,2 \\
\hline DNA target $(\approx 50 \mathrm{ng} / \mu \mathrm{L})$ & 0,15 & 0,5
\end{tabular}

\section{Statistical analysis}

The data were tabulated in spreadsheets of the Microsoft Excel $^{\circledR}$ software version 1910, with mean and standard deviation analysis of TC and TTC counts.

\section{Results and Discussion}

In assessing the hygienic and sanitary quality of the product, $100 \%$ of the samples surveyed were outside of the permitted standards for TC and TTC. Regarding TC, the estimates ranged from $9.3 \times 10^{5}$ to $1.1 \times 1010$ $\mathrm{MPN} / \mathrm{g}$ and an average (standard deviation - SD) of $1.1( \pm 2.3) \times 10^{9} \mathrm{MPN} / \mathrm{g}$ was obtained from all the samples. Regarding TTC, the results ranged from $4.3 \times 10^{5}$ to $2.4 \times 10^{9} \mathrm{MPN} / \mathrm{g}$, with an average (SD) of $4.5( \pm 7.5) \times 10^{8} \mathrm{MPN} / \mathrm{g}$, as shown in table 3 . In the quantification of CPS, of the 21 samples analyzed, 18 (85.71\%) had counts outside the standards acceptable by law, as shown in Table 4.

\section{Table 3}

Most Probable Number (MPN) of total and thermotolerant coliforms obtained from 21 Minas Frescal cheeses marketed in Araguaína, Tocantins, Brazil, in the period from April to June 2019

\begin{tabular}{lcc} 
MPN/g total coliforms $\left(30^{\circ} \mathrm{C}\right)$ & $\mathrm{n}$ of samples & Maximum limit (MAPA, 1996) \\
\hline up until $10^{5}$ & - & \\
$>10^{5}$ a $10^{7}$ & 08 & Até $105 \mathrm{MNP} / \mathrm{g}$ \\
$>10^{7}$ & 13 & \\
\hline MPN/g thermotolerant coliforms $\left(45^{\circ} \mathrm{C}\right)$ & $\mathrm{n}$ of samples & Maximum limit (ANVISA, 2001) \\
\hline up until $5,0 \times 10^{3}$ & - & \\
$>5,0 \times 10^{3}$ a $1,0 \times 10^{6}$ & 01 & Até $5,0 \times 103 \mathrm{MNP} / \mathrm{g}$ \\
$>10^{6}$ a $10^{8}$ & 07 & \\
$>10^{8}$ & 13 &
\end{tabular}


Table 4

Distribution of coagulase positive staphylococcal count (CPS) in 21 Minas Frescal cheeses marketed in Araguaína, Tocantins, from April to June 2019

CPS CFU/g

up until $10^{3}$

$>10^{3}$ a $10^{4}$

$>10^{4}$ a $10^{6}$

$>10^{6}$ n of samples

03

01

16

01
Of the 21 samples of MFCC analyzed, 17 showed colonies with characteristics suggestive of $E$. coli, totaling 476 isolates. This indicates contamination of fecal origin in $80.95 \%$ of the samples evaluated. Of the total E. coli isolates, 29 (6.09\%) were confirmed as EPEC; 70 (14.70\%) as STEC (60 - 12.60\% - stx 1 gene and 10 - $2.10 \%$ - stx 2 gene), and 1 (0.21\%) as EHEC (eaeA and stx genes simultaneously in the same isolate). As seen in Table 5 , it is possible that there was a recovery of clonal isolates in the same cheese sample, since the culture method had pre-enrichment. For example, from cheese sample 1, 20 isolates suggestive of $E$. coli were recovered, of which seven presented the stx 1 gene (possible clones) and another also presented the stx 1 gene; however, it was simultaneously positive for eaeA gene, being characterized as EHEC.
Of all MFCC samples, 52.38\% (11/21) presented isolates characterized as EPEC. Likewise, 52.38\% (11/21) and 14.28\% (03/21) presented positive $E$. coli isolates for st 1 and stx2 genes, respectively, making them positive for STEC. In addition, another sample $(01 / 21)$, which represents $4.76 \%$, presented isolates with simultaneous positivity for the and stx 1 genes, making it positive for EHEC. Analyzing only the MFCC samples with E. coli isolation (17/21), in $64.71 \%(11 / 17)$ of them, it was possible to recover positive isolates for the eae $A$ gene, and the same percentage of samples was found to be positive for st 1 gene, while $17.65 \%(03 / 17)$ presented positivity for stx2 gene. The distribution of isolates according to the MFCC sample evaluated is described in Table 5. 


\section{Table 5}

PCR results to identify the eaeA, stx 1 and stx2 genes of the $476 \mathrm{E}$. coli isolates from 21 clandestine Minas Frescal cheeses samples marketed in Araguaína, Tocantins, Brazil, from April to June 2019

\begin{tabular}{|c|c|c|c|c|}
\hline Cheese sample & $\mathrm{n}$ of isolates strains & eaeA (positive) & stx1 (positive) & stx2 (positive) \\
\hline $1^{*}$ & 20 & 1 & 8 & 0 \\
\hline 2 & 16 & 0 & 9 & 5 \\
\hline 3 & 0 & 0 & 0 & 0 \\
\hline 4 & 21 & 1 & 1 & 0 \\
\hline 5 & 9 & 0 & 2 & 0 \\
\hline 6 & 16 & 0 & 0 & 0 \\
\hline 7 & 0 & 0 & 0 & 0 \\
\hline 8 & 30 & 1 & 2 & 1 \\
\hline 9 & 23 & 1 & 4 & 0 \\
\hline 10 & 30 & 3 & 20 & 0 \\
\hline 11 & 16 & 1 & 3 & 0 \\
\hline 12 & 25 & 2 & 1 & 0 \\
\hline 13 & 57 & 14 & 0 & 0 \\
\hline 14 & 47 & 2 & 3 & 0 \\
\hline 15 & 21 & 0 & 0 & 4 \\
\hline 16 & 0 & 0 & 0 & 0 \\
\hline 17 & 61 & 2 & 7 & 0 \\
\hline 18 & 40 & 0 & 0 & 0 \\
\hline 19 & 30 & 0 & 0 & 0 \\
\hline 20 & 0 & 0 & 0 & 0 \\
\hline 21 & 14 & 1 & 0 & 0 \\
\hline Total & 476 & 29 & 60 & 10 \\
\hline
\end{tabular}

Legend: * The positive isolate for the eaeA gene was simultaneously for the stx 1 gene.

A total of 314 recovered isolates were suggestive of Salmonella spp. and 377, of Listeria spp., from the 21 MFCC samples. In the molecular search for gender-specific genes, no isolates were confirmed. Therefore, none of the MFCC samples tested positive for Salmonella spp. or Listeria spp.

A high average TC was found in the samples, with all estimates above the standard $\left(10^{5}\right)$ and 13 (61.90\%) above $10^{7} \mathrm{MPN} / \mathrm{g}$, which mainly shows the potential production of cheese using raw milk, in addition to the contamination environmental damage resulting from serious production failures, generally related to poor hygiene habits, handling without observing hygiene criteria, and poor sanitation of equipment and materials. The local productions that are subjected to inspection and registration by the competent public agencies aim to neutralize the critical points that can lead to contamination of the product. This scenario is very different from 
environments of homemade production that do not undergo inspection and control and, therefore, are more subjected to production and pasteurization failures, when existent.

This is reinforced by the study by Dias, Ferreira, Carvalho and Soares (2016), who attributed the high contamination by TC to the fact that the milk used in the manufacture of illegal cheeses is not subjected to pasteurization, while the possible contamination of inspected cheeses occurs by recontamination after pasteurization, due to excessive handling and hygiene failures. Barreto de Deus et al. (2017) reported high counts of TC in cheeses marketed informally on the beaches of the state of Bahia, attributing the high levels of deteriorating and pathogenic microorganisms to inadequate handling and marketing habits. The high TTC counts reported in this study may indicate contamination of fecal origin of the product. This is reinforced by the recovery of $E$. coli isolates in $81 \%(17 / 21)$ of the samples. Its detection may suggest the presence of other pathogenic microorganisms of enteric origin. Therefore, they are often used as indicators of potential fecal contamination, direct or indirect, and of the potential risk of the presence of pathogens in zoonotic foods (Franco \& Landgraf, 2002).

Several studies have witnessed TTC levels above what is allowed by legislation in cheeses (Amorim et al., 2014; Apolinário, Santos, \& Lavorato, 2014; Dias et al., 2016; Barreto de Deus et al., 2017; I. A. Souza et al., 2017). This is probably due to failures in cheese processing, either due to an inadequate hygiene of materials and equipment, or improper hygiene habits of the handlers that work in the dairy plants. It could not even be fully guaranteed that all the cheeses derived from industrial establishments registered with the competent health agency were in accordance with the legislation (Amorim et al., 2014; Dias et al., 2016), although they still showed better microbiological quality than non-inspected cheeses and, potentially, less risk to public health.

According to Murray, Rosenthal, Kobayashi and Pfaller (2014), EPEC is considered an important cause of childhood diarrhea in poor countries, and the disease is rarer in adolescents and adults due to the development of protective immunity. More than half of the evaluated samples (52.38\%) were positive for EPEC; thus, the MFCC marketed in the municipality may cause outbreaks of foodborne diseases. Milk pasteurization before cheese production would eliminate the possibility of the presence of this pathogen, that is derived from raw milk.

Other studies demonstrate that not only the MFCC assessed by this work in the municipality of Araguaína has this potential for public health risk. Campos et al. (2018) also detected an isolate of 147 cheese samples from raw EPEC-positive milk. Further Ribeiro et al. (2019) identified two isolates from 10 evaluated samples of clandestine cheeses.

The presence of the stx 1 and stx 2 genes in 52.38\% (11/21) and $14.28 \%(03 / 21)$ of the samples, respectively, are reasons for great concern. STEC is characterized by the production of a cytotoxin named Shiga toxin, encoded by the stx 1 and st 2 genes (Nataro \& Kaper, 1998; Paton \& Paton 1998; Gomes et al., 2016). STEC strains are found in raw milk and raw milk cheeses (Farrokh et al., 2013) and are an important cause of human outbreaks, causing severe hemolytic uremic syndrome (HUS) and purple thrombocytopenia (Paton \& Paton, 1998; Miszczycha et al., 2014). 
As reported (Paton \& Paton, 1998; Farrokh et al., 2013), the stx2 virulence gene is the most important type of stx gene, because it has been shown that the probability of developing HUS during infection is greater when stx2 producing STEC is involved. Considering that almost $15 \%$ of the samples in the present study had E. coli colonies positive for this gene, it is possible that the consumption of illegal MFCC can be related to serious cases of infection and complications in humans.

The number of isolates suggestive of E. coli tested (476) compared to the number of samples evaluated (21) was of fundamental importance, in order to detect the presence of the eae $A$ and stx genes in an isolate simultaneously, characterizing it as EHEC, which corresponds to $4.76 \%(01 / 21)$ of the evaluated samples. The detection of this type of $E$. coli is very serious, given the severe disease caused by EHEC. On the other hand, Ribeiro et al. (2019) did not detect this simultaneity in 114 isolates from 10 samples of formal and 10 informal cheeses, although, as in this study, the presence of STEC and EPEC strains was also detected in clandestine samples.

Comparing this study with that of Campos et al. (2018), who detected only one isolate $(0.68 \%)$ positive for the eae $A$ gene from 147 of the tested samples, the results presented here are expressive and can be much higher if it is taken into account that $47.6 \%(10 / 21)$ of the samples showed positive strains for st $x$ and eae $A$, but not simultaneously for both. Independently of the virulence factor characterization, the fact that it is verified that E. coli was isolated, by itself, is already a result that may imply a health risk associated to consumption due to the potential occurrence of other enteropathogens.
Staphylococcus coagulase-positive indicates contamination related to failures during milk pasteurization, such as an inadequate weather or temperature, and recontamination during manual handling (Mehli, Hoel, Bjorge, Nordeng, \& Karlsen, 2017). When present in high concentration $\left(10^{5}-10^{6}\right.$ $\mathrm{CFU} / \mathrm{mL}$ or $\mathrm{g}$ ) and under appropriate conditions of temperature, $\mathrm{pH}$, water activity, and $\mathrm{O}_{2^{\prime}}$ they produce one or more staphylococcal enterotoxins in food, which after ingestion, can cause poisoning (Hobbs \& Roberts, 1999; Borges, Nassu, Pereira, Andrade, \& Kuaye, 2008).

Several studies have shown the presence of CPS above the limits allowed by the Brazilian legislation for different types of cheese. Arruda, Nicolau, Reis, Araújo and Mesquita (2007) found the presence of CPS above the permitted values in the analysis of 42 samples of Minas Frescal cheese sold in open street markets in the city of Goiânia-GO, attributing this high contamination to the fact that the product is being sold in street open markets, thus having greater handling, which facilitated contamination. Amorim et al. (2014) found that $100 \%$ of informal Minas Frescal cheese samples showed high CPS counts, which varied from $2.5 \times 10^{6}$ to $1.75 \times 10^{7} \mathrm{CFU} / \mathrm{g}$.

The clear deficiency of physical structure noted in street open markets, such as the absence of drinking water for hand hygiene, in addition to the production of cheese without the thermal treatment of milk, only aggravates the possibility of product contamination by Staphylococcus spp. This generates high counts in food, as the commensal pathogen of the skin could be reduced by having the simple hand hygiene habits and by pasteurizing the raw material. We did not confirm the presence of Salmonella spp. in the evaluated 
samples. However, it is important to note that microorganisms of this genus are present mainly in the intestines of birds and pigs, and contamination of products ready for consumption may occur if, in the production environment, there are factors and conditions that lead to a direct or indirect contact, mainly, with the feces of these animals. In addition, the isolation of $E$. coli represents a risk of the occurrence of enteropathogens, which were perhaps not detected in this sample unit.

In a United States Food and Drug Administration (FDA) study, only two of 885 samples of cheese produced from raw milk were positive for Salmonella spp., which demonstrated an occurrence of $0.22 \%$ of positive samples (Correll, 2014). Thus, using this proportionality, if the present study had evaluated a larger number of samples, the detection of Salmonella spp. could have been identified. In addition, factors such as high TC and TTC counts favor the inhibition of pathogenic microbiota, such as Salmonella spp., due to a reduced pH (Trmcic et al., 2016). The presence of lactic acid bacteria in raw milk, with bacterial antagonism to pathogens and production of acids and peroxides with antimicrobial action (Beloti, 2015) can also justify the absence of this pathogen in the tested samples.

Of the 21 samples analyzed, none were positive for Listeria spp. The study by Dailey, Martin and Smiley (2014) also did not identify the presence of $L$. monocytogenes in several samples of food products, including cheese, attributing the intense presence of aerobic mesophilic, coliform, and Staphylococcus bacteria to the limiting factor in the multiplication of Listeria spp. Considering that microorganisms of this species may be psychrotrophic, raw refrigerated products may pose a greater risk for the presence of Listeria spp. However, a low temperature control was observed in the market regarding the storage of MFCC samples evaluated in the present study, often stored in cool boxes, without ice, and exposed to the sun. Although the presence of enteropathogens, such as E. coli, in the present study was confirmed as an indicator of fecal contamination, the high counts of TC and TTC may also explain the absence of $L$. monocytogenes, which may be present in the intestines of animals, but not being detected. The intense microbial population results in a dispute over nutrients, oxidative stress, and $\mathrm{pH}$ reduction, causing difficulties in multiplication and, consequently, seasonality or bacterial death (Beloti, 2015).

In short, public policies must be implemented in order to train producers to have good manufacturing practices and technologies to produce cheeses from pasteurized milk and in a hygienic way, to reduce the bureaucracy of the registration of products produced by family farming, so that the product reaches the consumer's table with quality and safety. A sanitary inspection agency must carry out training programs with producers and traders in production and sale, legalizing production and marketing. In addition, it is necessary to implement consumer awareness actions to purchase only registered products and to commercialize in adequate conditions of hygiene and storage, minimizing the health risks.

\section{Conclusion}

The high count of total and thermotolerant coliforms evidenced in the MFCC samples shed a light on unsatisfactory sanitary conditions in the production, storage, 
and/or commercialization of this food product. The manufacturing of these products from raw milk can be the main reason for the presence of pathogens and other indicators in high quantities in the product. The presence of $E$. coli, EPEC, STEC, EHEC, and coagulase-positive staphylococci at high concentrations shows an imminent health risk from the consumption of MFCCs.

\section{Acknowledgment}

This study was funded by the Research Program for SUS (PPSUS), Tocantins Research Support Foundation (FAPT), and National Institute of Science and Technology of the Milk Production Chain (CNPq - 305062/2015-8, CAPES, FINEP, and Araucária Foundation (PR). This work was also carried out with support from the National Academic Cooperation Program in the Amazon - PROCAD/Amazon of the Coordination for the Improvement of Higher Education Personnel - CAPES/Brazil.

\section{References}

Amorim, A. L. B. C., Couto, E. P., Santana, A. P., Ribeiro, J. L., \& Ferreira, M. A. (2014). Avaliação da qualidade microbiológica de queijos do tipo Minas padrão de produção industrial, artesanal e informal. Revista do Instituto Adolfo Lutz, 73(4), 364-367. doi: 10.18241/0073-98552014731628

Apolinário, T. C. C., Santos, G. S., \& Lavorato, J. A. A. (2014). Avaliação da qualidade microbiológica do queijo minas frescal produzido por laticínios do estado de Minas Gerais. Revista do Instituto Laticínios Cândido Toste, 69(6), 433-442. doi: 10.14295/2238-6416.v69i6.290
Argudín, M. A., Mendoza, M. C., \& Rodicio, M. R. (2010). Food poisoning and Staphylococcus aureus enterotoxins. Toxins, 2(7), 1751-1773. doi: 10.3390/ toxins 2071751

Arruda, M. L. T., Nicolau, E. S., Reis, A. P., Araújo, A. S., \& Mesquita, A. J. (2007). Ocorrência de Staphylococcus coagulase positiva em queijos tipos Frescal e Padrão comercializados nas feiras-livres de Goiânia - GO. Revista do Instituto Adolfo Lutz, 66(3), 292-298. Recuperado de http://periodicos.ses.sp.bvs.br/scielo. php?script $=$ sci_arttext $\&$ pid $=$ S0073-985 $52007000300013 \&$ lng $=p t$

Anvisa (2001). Agencia Nacional de Vigilância Sanitária. Resolução de Diretoria Colegiada no 12, de 2 de janeiro de 2001. Regulamento Técnico sobre padrões microbiológicos para alimentos, Diário Oficial da União, Brasília.

Barreto de Deus, T., Barros, L. S. S., Silva, R. M., Lima, W. K. S., Lima, D. D. V., \& Silva, A. S. (2017). Staphylococcus aureus and Escherichia coli in Curd Cheese Sold in the Northeastern Region of South America. International jornal of Microbiology, 2017(1), 8173741. doi: $10.1155 / 2017 / 8173741$

Beloti, V. (2015). Leite: obtenção, inspeção e qualidade. Londrina: Editora Planta.

Borges, M. F., Nassu, R. T., Pereira, J. L., Andrade, A. P. C., \& Kuaye, A. Y. (2008). Perfil de contaminação por Staphylococcus e suas enterotoxinas e monitorização das condições de higiene em uma linha de produção de queijo de coalho. Ciência Rural, 38(5), 1431-1438. doi: 10.1590/ S0103-847820080005000 37 
Ministério da Agricultura, Pecuária e Abastecimento (1996). Portaria no 146, de 07 de março de 1996. Aprova os regulamentos técnicos de identidade e qualidade dos produtos lácteos, Diário Oficial da República Federativa do Brasil, Poder Executivo, Brasília.

Campos, A. C. L. P. de, Puño-Sarmiento, J. J., Medeiros, L. P., Gazal, L. E. S., Maluta, R. P., Navarro, A.,... Nakazato, G. (2018). Virulence Genes and Antimicrobial Resistance in Escherichia coli from Cheese Made from Unpasteurized Milk in Brazil. Foodborne Pathogens Disease, 15(2), 94-100. doi: $10.1089 / \mathrm{fpd} .2017 .2345$

Carmo, L. S., Dias, R. S., Linardi, V. R., Sena, M. J., Santos, D. A., Faria, M. E.,... Heneine, L. G. (2002). Food poisoning due to enterotoxigenic strains of Staphylococcus present in Minas cheese and raw milk in Brazil. Food Microbiology, 19(1), 9-14. doi: 10.1006/fmic.2001.0444

, Y., \& Knabel, S. J. (2007). Multiplex PCR for simultaneous detection of bacteria of the genus Listeria, Listeria monocytogenes, and major serotypes and epidemic clones of L. monocytogenes. Applied and Environmental Microbiology, 73(19), 6299-6304. doi: 10.1128/AEM.00961-07

Correll, W. A. (2014). Letter to American Cheese Society (ACS) with an update on what has been done with respect to non-toxigenic Escherichia coli (E. coli) in raw milk cheese. Public Health Service, Food and Drug Admin, College Park, MD.

Costa, G. M. D., Pereira, U. D. P., Custódio, D. A. D. C., \& Silva, N. D. (2011). Caracterização de Staphylococcus coagulase-positiva utilizando plasmas de diferentes espécies animais. Revista do Instituto Adolfo Lutz, 70(4), 584-588. Recuperado de http://periodicos.ses. sp.bvs. br/scielo.php? script= sci_artte xt\&pid=S0073-98552011000400021 \&lng=pt\&nrm=iso

Cruz, C. D., Martinez, M. B., \& Destro, M. T. (2008). Listeria monocytogenes: um agente infecciosoaindapoucoconhecidonoBrasil. Alimentos e Nutrição Araraquara, 19(2), 195-206. Recuperado de https://www. researchgate.net/publication/49599808_ Listeria_monocytogenes_UM_AGENTE_ INFECCIOSO_AINDA_POUCO_ CONHECIDO_NO_BRASIL

Dailey, R. C., Martin, K. G., \& Smiley, R. D. (2014). The effects of competition from nonpathogenic foodborne bacteria during the selective enrichment of Listeria monocytogenes using buffered Listeria enrichment broth. Food Microbiology, 44, 173-179. doi: 10.1016/j.fm.2014. 05.004

Dias, B. F., Ferreira, S. M., Carvalho, V. S., \& Soares, D. S. B. (2016). Qualidade microbiológica e físico-química de queijo minas frescal artesanal e industrial. Journal of Neotropical Agriculture, 3(3), 57-64. doi: 10.32404/rean.v3i3.1211

Elbagory, A. M., Eman, S. H., \& Eman, K. F. (2015). Impact of probiotic strains on growth of some food poisoning bacteria from milk and soft cheese. Nutrition and Food Technology, 1(2). doi: 10.16966/ 24706086.107

Fai, A. E. C., Figueredo, E. A. T., Verdin, S. E. F., Pinheiro, N. M. S., Braga, A. R. C., \& Stamford, T. L. M. (2011). Salmonella sp e Listeria monocytogenes em presunto suíno comercializado em supermercados 
de Fortaleza (CE, Brasil), fator de risco para a saúde pública. Ciência \& Saúde Coletiva, 16(2), 657-662. doi: 10.1590/ S1413-81232011000200029

Farrokh, C., Jordan, K., Auvray, F., Glass, K., Oppegaard, H., Raynaud, S.,... Cerf, O. (2013). Review of Shiga-toxinproducing Escherichia coli (STEC) and their significance in dairy production. International. Journal of. Food Microbology, 162(2), 190-212. doi: 10.1016/j.ijfoodmicro.2012.08.008

Franco, B. D. G. M., \& Landgraf, M. (2002). Microbiologia dos alimentos. São Paulo: Atheneu.

Gomes, T. A. T., Elias, W. P., Scaletsky, I. C. A., Guth, B. E. C., Rodrigues, J. F., Piazza, R. M. F.,... Martinez, M. B. (2016). Diarrheagenic Escherichia coli. Brazilian Journal of medical Microbioly, 47(Suppl. 1), 3-30. doi: 10.1016/j.bjm.2016.10.015

Hobbs, B. C., \& Roberts, D. (1999). Toxinfecções e controle higiênico-sanitário de alimentos. São Paulo: Varela.

Johler, S., Wender, D., Bridy, C., Huguenin, M. C., Robert, L., Hummerjohann, J., \& Stephan, R. (2015). Outbreak of staphylococcal food poisoning among children and staff at a Swiss boarding school due to soft cheese made from raw milk. Journal od Dairy Science, 98(5), 2944-2948. doi: 10.3168/jds.2014-9123

Lopes, M. A., Carmo, E. A., Lima, A. L. R., \& Carvalho, F. M. (2006). Análise de rentabilidade de uma empresa com opção de comercialização de queijo ou leite. Arquivo Brasileiro de Medicina Veterinária e Zootecnia, 58(4), 642-647. doi: 10.1590/ S0102-09352006000400028
Mehli, L., Hoel, S., Bjorge, G. M., Nordeng, A., \& Karlsen, H. (2017). The prevalence, genetic diversity and antibiotic resistance of Staphylococcus aureus in milk, whey, and cheese from artisan farm dairies. International Dairy Journal, 65(1), 20-27. doi: 10.1016/j.idairyj.2016.10.006

Miszczycha, S. D., Thevenot, J., Denis, S., Callon, C., Livrelli, V., Alric, M.,... ThevenotSergentet, D. (2014). Survival of Escherichia coli O26:H11 exceeds that of Escherichia coli 0157:H7 as assessed by simulated human digestion of contaminated raw milk cheeses. International Journal Food Microbiology, 172(1), 40-48. doi: 10.1016/j. ijfoodmicro.2013.11.029

Murray, P. R., Rosenthal, K. S., Kobayashi, G. S., \& Pfaller, M. A. (2014). Microbiologia médica (7a ed.). Rio de Janeiro: Elsevier.

Nataro, J. P., \& Kaper, J. B. (1998). Diarrheagenic Escherichia coli. Clinical Microbiology Reviews, 11(1), 142-201. doi: 10.1128/ CMR.11.1.142

Paton, A. W., \& Paton, J. C. (1998). Detection and characterization of shiga toxigenic Escherichia coli by using multiplex PCR assays for stx1, stx2, eaeA, enterohemorrhagic $E$. coli hlyA, rfb 0111, andrfb 0157. Journal Clinica IMicrobiology, 36(2), 598-602. doi: 10. 1128/CMR.11.1.142

Ribeiro, J. C., Jr., Silva, F. F., Lima, J. B. A., Ossugui, E. H., Teinder, P. I., Jr., Campos, A. C. L. P.,... Beloti, V. (2019). Short communication: Molecular characterization and antimicrobial resistance of pathogenic Escherichia coli isolated from raw milk and Minas Frescal cheeses in Brazil. Journal of Dairy Science, 102(12), 10850-10854. doi: 10.3168/jds.2019-16732 
Ribeiro, J. C., Jr., Tamanini, R., Soares, B. F., Oliveira, A. M., Silva, F. G., Silva, F. F.,... Beloti, V. (2016). Efficiency of boiling and four other methods for genomic DNA extraction of deteriorating sporeforming bacteria from milk. Semina: Ciências Agrárias, 37(5), 3069-3078. doi: 10.5433/1679-0359. 2016v37n5 p3069

Salvador, F. C. (2012). Avaliação da qualidade microbiológica do leite pasteurizado comercializado em Apucarana-PR e região. Revista Fapciências, 9(5), 30-41. Recuperado de https://docplayer.com. br/222 54320-Avaliacao-da-qualidademicrobiologica-do-leite-pasteurizadocomercializado-em-apucarana-pr-e -regiao.html

Sato'o, Y., Omoe, K., Naito, I., Ono, H. K., Nakane, A., Sugai, M.,... Hu, D. L. (2014). Molecular epidemiology and identification of a Staphylococcus aureus clone causing food poisoning outbreaks in Japan. Journal Clinical Microbiology, 52(7), 26372640. doi: 10.1128/JCM.00661-14

Shanmugasamy, M., Velayutham, T., \& Rajeswar, J. (2011). InvA gene specific PCR for detection of Salmonella from broilers. Veterinari World, 4(12), 562-564. doi: 10.5455/vetworld.2011.562-564

Silva, J. A., \& Silva, D. (2005). Escherichia coli Enteropatogênica (EPEC), ao contrário da Echerichia coli comensal, adere, sinaliza e lesa enterócitos. Revista de Patologia Tropical, 34(3), 175-196. doi: 10. 5216/rpt. v34i3.1925

Silva, N., Junqueira, V. C. A., Silveira, N. F. A., Taniwaki, M. H., Gomes, R. A. R., \& Okazaki, M. M. (2017). Manual de métodos de analises microbiológica de alimentos e água (5a ed.). São Paulo: Blucher.
Souza, C. D. O., Melo, T. R. B., Melo, C. D. S. B., Menezes, Ê. M., Carvalho, A. C. D., \& Monteiro, L. C. R. (2016). Escherichia coli enteropatogênica: uma categoria diarreiogênica versátil. Revista PanAmazônica de Saúde, 7(2), 79-91. doi: 10.5123/S2176-62232016000200010

Souza, I. A., Giovannetti, A. C. S., Santos, L. G. F., Gandra, S. O. S., Martins, M. L., \& Ramos, A. L. S. (2017). Qualidade microbiológica de queijo minas frescal comercializado na zona da mata mineira. Revista do Instituto Laticínios Cândido Tostes, 72(3), 152-162. doi: 10.14295/2238-6416.v72i3.598

Teider, P. I., Jr., Ribeiro, J. C., Jr., Ossugui, E. H., Tamanini, R., Ribeiro, J., Santos, G. A.,... Beloti, V. (2019). Pseudomonas spp. and other psychrotrophic microorganisms in inspected and non-inspected Brazilian Minas Frescal Cheese: proteolytic, lipolytic and AprX production potential. Pesquisa Veterinária Brasileira, 39(10), 807-815. doi: 10.1590/1678-5150-PVB-6037

Trmcic, A., Chauhan, K., Kent, D. J., Ralyea, R. D., Martin, N. H., Boor, K. J., \& Wiedmann, M. (2016). Coliform detection in cheese is associated with specific cheese characteristics, but no association was found with pathogen detection. Jounal of Dairy Science, 99(8), 6105-6120. doi: 10.3168/jds.2016-111 12

Vigilância Epidemiológica do Município de Araguaína-TO (2019). Comunicação pessoal. Araguaína: Secretaria Municipal de Saúde de Araguaína. TO.

World Health Organization (2019). Saumonella (no-typhoidal). Retrieved from https:// www.who.int/news-room/fact-sheets/ detail/salmonella-(non-typhoidal) 